\begin{tabular}{|l|l|l|l}
\hline Verh. Internat. Verein. Limnol. & 27 & $1780-1783$ & Stuttgart, December 2000 \\
\hline
\end{tabular}

\title{
Trophic interactions: changes in phytoplankton community structure coinciding with alewife introduction (Alosa pseudoharengus)
}

\author{
Joseph C. Makarewicz
}

\section{Introduction}

Conesus Lake is a eutrophic lake (Mills 1975) and the most western of the Finger Lakes of New York State, USA. Abundance of a top level predator, the walleye (Stizostedion vitreum vitreum), decreased from a high of 12,000 individuals in 1966 to 9,614 individuals in 1975 to 1,850 individuals by 1985 in Conesus Lake (ABRAHAM 1989). Coincidental with the decline of the walleye in Conesus Lake was the proliferation of an obligate planktivore, Alosa pseudoharengus (AвRAHAm 1988). During the late 1970s (probably 1978 or 79), the alewife was accidentally introduced and became established in the lake. The pre-alewife zooplankton community was dominated by Daphnia pulex, Conochilus unicornis and Cyclops bicuspidatus. The overwhelming dominance of $D$. pulex in 1972 was impressive. It was the dominant cladoceran on each of the 50 sampling days throughout the year (CHAMBERLAIN 1975). Abundance reached as high as 36 individuals/L in the summer and 13 individuals/L in December. The pre-alewife phytoplankton community was dominated by larger $(>70 \mu \mathrm{m}$, greatest axial linear dimension) colonial, filamentous and unicelluar algae or net phytoplankton (Mills 1975). With excellent historical phytoplankton and zooplankton data available, an opportunity existed to examine the impact of alewife introduction on plankton community structure in a large-lake ecosystem $\left(13.7 \mathrm{~km}^{2}\right)$ over a 16-year period.

\section{Methods}

Water and plankton samples from Conesus Lake were collected biweekly from May to November in 1985 and 1988. Water samples were taken with a Van Dorn bottle (non-metallic) at depths of 1,8 and $12 \mathrm{~m}$. Twenty-five milliliters of water were filtered (0.45- $\mu \mathrm{m}$ Magma Nylon 66 filter) in the field and stored in ice. Total phosphorus (TP) and soluble reactive phosphorus (SRP) were determined by automated techniques (APHA 1985). Chlorophyll was collected on GF/F filters and analyzed fluorometri- cally (WeTZEL \& Likens 1979). Zooplankton were sampled with a Wisconsin net $(0.5-\mathrm{m}$ diameter, $0.80-\mu \mathrm{m}$ mesh net) equipped with a calibrated flow meter. Vertical tows were from $1 \mathrm{~m}$ off the bottom to the surface. Zooplankton were relaxed with tonic water and preserved in 5\% formalin. Triplicate counts were made with a Sedgewick-Rafter cell. Cyclopoids were identified and counted separately under a dissecting scope. Where possible, up to 50 length measurements per sampling date were made of each species of Crustacea observed (10 for Rotifera). The phytoplankton sample $(100 \mathrm{~mL})$ was taken at a depth of $1 \mathrm{~m}$ and preserved with $0.5 \%$ glutaraldehyde. Enumeration and appropriate axial dimensions to calculate biomass from geometric shapes were from permanent slides (BERGQUIST et al. 1985, CRUMPTON 1987). The data were grouped by year and analyzed by one-way ANOVA $(\mathrm{P}<0.05)$. Post hoc multiple range tests on the independent variable years included Least Significant Difference and Bonferroni tests.

\section{Results and discussion}

The post-alewife (1985 and 1988) zooplankton species composition represented a significant change since 1973 (pre-alewife). In 1973, Conesus Lake was dominated by the large Daphnia pulex, the colonial rotifer Conochilus unicornis and Cyclops bicuspidatus (CHAMBERLAIN 1975). As a result of the introduction of the alewife into Conesus Lake in 1978-79, the cladoceran community changed and was dominated by the small Bosmina longirostris by 1985 . The smaller Daphnia retrocurva was the second most important Cladocera while D. galeata mendotae was somewhat rare in 1985. The last D. pulex was observed in 1984. Cyclops bicuspidatus and Conochilus unicornis were the dominant Copepoda and Rotifera in 1985, as in 1973 (MAKAREWICZ 1986). 
With continued size-selective feeding by the alewife, further changes in the zooplankton community were observed by 1988 . B. longirostris and Ceriodaphnia reticulata were codominant in 1988, while the 1985 codominant $D$. retrocurva was rare in 1988. As in 1985, D. pulex was not present in the lake. A large Copepoda, Diaptomus pallidus (length $\sim 1 \mathrm{~mm}$ ), present in 1985 but with a reduced abundance compared to 1972 , was completely eliminated by $1988-9$ years after the introduction of alewife. Similarly, the abundance and size of Cyclops bicuspidatus thomasi decreased from $1985(12.3 \%$ of the Crustacea abundance; mean length of $0.92 \mathrm{~mm})$ to $1988(0.20 \%$ of the Crustacea abundance; mean length of 0.72 mm) (Puckett 1989). Wells (1970) reported similar losses of the largest cladocerans, calanoids and the largest cyclopoid copepod (Mesocyclops edax) from the waters of southeastern Lake Michigan when alewife abundance increased.

In general, the average crustacean biomass significantly decreased from a pre-alewife high of $228 \mathrm{mg} / \mathrm{m}^{3}$ in 1972 to post-alewife lows of 182 and $99 \mathrm{mg} / \mathrm{m}^{3}$, respectively (Table 1 ). Concomitantly, the weighted mean length of the Crustacea significantly decreased from 1.03 $\mathrm{mm}$ in 1972 (pre-alewife) to $0.47 \mathrm{~mm}$ in 1985 (post-alewife) down to $0.29 \mathrm{~mm}$ in 1988 (Table 1). Even the dominant and small crustacaean Bosmina longirostris decreased in average size (0.32 $\mathrm{mm}$ in 1985 to $0.26 \mathrm{~mm}$ in 1988). By $1988,98 \%$ of the crustacean community was less than $0.35 \mathrm{~mm}$ in length. Conesus Lake is a classic example of size-selective predation by planktivorous fish that has resulted in a shift in prey composition to smaller zooplankton. Many experimental and field studies have documented similar size-related effects on zooplankton community structure (See McQueEN et al. 1989 for a review).

The significant increase in abundance of rotifers (Table 1) in Conesus Lake is consistent with both the indirect and direct evidence that suggested that rotifers were more prevalent in the absence of exploitative and interference competition from Daphnia (GILBERT 1988). Similarly, the significant increase in ambient soluble reactive phosphorus (Table 1) appeared to be a size-related consequence, even though ambient total phosphorus concentrations had not changed. Since the excretion of phosphorus by zooplankton is inversely proportional to body size (Peters \& Rigler 1975), a reduction in average size of the zooplankton community induced by size-selective predation might increase community excretion rates. HENRY (1985) tested this hypothesis and experimentally demonstrated that phosphorus release rates were higher in zooplankton communities dominated by smaller zooplankton than those dominated by larger ones. Similarly in Conesus Lake, the increase in SRP from 1985 to 1988 occurred when zooplankton body size decreased (Table 1).

A major shift in size composition of the phytoplankton community occurred from the preto the post-alewife period. In 1972, the net plankton $(>70 \mu \mathrm{m})$ represented over $61 \%$ of the total phytoplankton biomass. By 1985 and 1988 , net plankton biomass decreased to less than $22 \%$ of the total phytoplankton biomass (Table 1), that is, the biomasses of smaller size classes of phytoplankton were becoming more prevalent after the introduction of alewife and the selective removal of large Cladocera. Northcote et al. (1990) and Bergquist et al. (1985) observed a similar response to the removal of large-bodied cladocerans, where relative abundance of small phytoplankton in the $<25-\mu \mathrm{m}$ range decreased. Although the overall size of the Conesus Lake phytoplankton community decreased, it was at the $21-$ to $70-\mu \mathrm{m}$ size range rather than the $<25-\mu \mathrm{m}$ size range as BERGQUIST et al. (1985) observed.

\section{Trophic interactions}

Various classification schemes indicate that Conesus Lake is a eutrophic lake (Mills 1975). Even so, chlorophyll levels prior to the introduction of alewife were much lower than those expected based on ambient winter total phosphorus concentrations. The regression model of Oglesby \& SCHAFFner $(1978)(\mathrm{Chl}=0.574[\mathrm{~T}]$ $-2.90, r^{2}=0.82$, where $T$ represents the winter total phosphorus levels) derived from data on 16 Finger Lakes of New York, including Cone- 
Table 1. Summary of selected biological and chemical data from 1972, 1985 and 1988, Conesus Lake. NA, not available. Values represent the average for the May through October period, unless stated otherwise. Phytoplankton size class data are percent of biomass. One star $\left(^{*}\right)$ indicates a significant difference from $1972(\mathrm{P}$ $<0.05)$. Two stars $\left(^{* *}\right)$ indicate a significant difference from 1972 and $1985(\mathrm{P}<0.05)$.

\begin{tabular}{|c|c|c|c|}
\hline & 1972 & 1985 & 1988 \\
\hline \multicolumn{4}{|l|}{ Chemistry $(\mu \mathrm{g} P / \mathrm{L})$} \\
\hline Total phosphorus & $23^{a}$ & 26.5 & 23.5 \\
\hline Soluble reactive phosphorus & $4.4^{\mathrm{b}}$ & $5.8^{c}$ & $13.5^{* * c}$ \\
\hline Turbidity (NTU) & 0.81 & $1.05^{*}$ & $1.52^{* *}$ \\
\hline \multicolumn{4}{|l|}{ Zooplankton biomass $\left(\mathrm{mg} / \mathrm{m}^{3}\right)$} \\
\hline Crustacea & $228^{d}$ & 182 & $99^{* *}$ \\
\hline Calanoida & 30 & $7^{*}$ & 0 \\
\hline Cladocera & 146 & $62^{*}$ & $84^{*}$ \\
\hline Daphnia spp. & 87 & $23^{*}$ & $3^{* *}$ \\
\hline Rotifera (ind./L) & NA & 567 & $1,235^{* *}$ \\
\hline \multicolumn{4}{|l|}{ Zooplankton length (mm) } \\
\hline Crustacea & 1.03 & $0.47^{*}$ & $0.29^{* *}$ \\
\hline Crustacea + Rotifera & 0.60 & $0.23^{*}$ & $0.18^{* *}$ \\
\hline \multicolumn{4}{|l|}{ Phytoplankton } \\
\hline Chlorophyll ( $\mu \mathrm{g} / \mathrm{L})$ & $3.4^{\mathrm{c}}$ & 3.8 & $7.3^{* *}$ \\
\hline Abundance (cells/mL) & $1,803^{\mathrm{e}}$ & 1,068 & 3,076 \\
\hline \multirow[t]{4}{*}{ Size class } & $20.5 \%^{\mathrm{c}}$ & $10.2 \%$ & $24.2 \%$ \\
\hline & $13.7 \%^{\mathrm{e}}$ & $29.3 \%$ & $13.2 \%$ \\
\hline & $4.2 \%^{\mathrm{e}}$ & $39.3 \%$ & $43.4 \%$ \\
\hline & $61.6 \%{ }^{\mathrm{e}}$ & $21.2 \%$ & $19.2 \%$ \\
\hline
\end{tabular}

${ }^{2} 1969$ data of STEWART \& MARKELLO (1974). Graphical accuracy for the May through October period.

${ }^{b} 1972$ data of OGLESBY et al. (1978). Data represent the stratification period: May 31 to September 26.

'Means are for the period May 25 to September 30.

${ }^{\mathrm{d}}$ The 1972 biomass estimate represents the weighted mean for June through October of 1972. A net efficiency of $77.3 \%$ was applied to the 1972 data based on our 1985 data. Because a $150-\mu \mathrm{m}$ mesh net was used in 1972, the 1972 biomass estimates are believed to be conservative (graphical accuracy, CHAMBERLAIN 1975). Copepod nauplii are not included in the biomass estimates.

${ }^{c} 1972$ data of Mills (1975). Data represent the stratification period: May 31 to September 26.

sus Lake, predicted summer chlorophyll levels that were $29 \%$ higher $\left(7.2 \mathrm{mg} / \mathrm{m}^{3}\right)$ than observed $\left(5.6 \mathrm{mg} / \mathrm{m}^{3}\right)$ in 1972 . In the early 1970 s when the regression model was constructed, most of the Finger Lakes were inhabited with alewife, with the notable exception of Conesus Lake until 1979. The lower chlorophyll levels in Conesus Lake were apparently maintained by the presence and dominance of the large-bodied Cladocera, Daphnia pulex. The statement of FOREST et al. (1978) that "Effective grazing by a single crustacean, Daphnia, helps keep the open water clear most of the time" was perceptive. Although a refugium for
Daphnia pulex did not exist, the abundant population of $D$. pulex was apparently maintained by low size-selective predation pressure from planktivores (mostly yellow perch). After the introduction of alewife and the removal of $D$. pulex, chlorophyll a concentrations have increased $(-7.3$ for the stratified period, Table 1 ) and are now consistent with the predictions of the regression model.

The top-down:bottom-up (TD:BU) model (McQueEn et al. 1989) predicts that in a eutrophic lake with an established population of large-bodied zooplankton, such as Daphnia pulex, decimation of the large-bodied cladoce- 
ran by size-selective feeding of a planktivore should result in an increase in phytoplankton biomass. The Conesus Lake data support this corollary of the TD:BU model (Table 1). With decreasing intersummer zooplankton biomass, there was an increase in summer chlorophyll $a$ concentrations, that is, a negative correlation $(\mathrm{r}=-0.98, \mathrm{n}=3)$ existed between the intersummer chlorophyll and zooplankton biomass. Admittedly, more interannual data points are desirable. However, the similarity in summer total phosphorus concentration between years (Table 1) suggests that the changes in chlorophyll observed were not due to bottom-up effects. Together these results suggest that trophic level biomass at the primary producer level can and is controlled by a top-down effect under the conditions described for Conesus Lake. These data are consistent with predictions made by the top-down:bottom-up model, and the implication is that in Conesus Lake the trophic cascade does not uncouple or dampen out at the zooplankton-phytoplankton link.

\section{Acknowledgements}

E. Mills and K. STEWART provided unpublished portions of pre-alewife data, while B. CADY, G. CREGO, and N. PUCKETT provided valuable assistance in the field. I thank them for their data and help.

\section{References}

Aвraham, W. J., 1988: Colonization of Conesus Lake by the alewife.- Bureau of Fisheries Report. - New York State Department of Environmental Conservation (NYSDEC), Avon, N.Y., USA.

Aвraham, W. J., 1989: Conesus Lake fish stock assessment comparisons between 1985 and 1988 netting data. Bureau of Fisheries Report. - New York State Department of Environmental Conservation (NYSDEC), Avon, N.Y., USA.

APHA, 1985: Standard Methods for the Examination of Water and Wastewater, 16th ed. - American Public Health Association. Washington, D.C., USA. 1268 pp.

Bergquist, A. M., Carpenter, S. R. \& Latino, J. C., 1985: Shifts in phytoplankton size structure and community composition during grazing by contrasting zooplankton assemblages. - Limnol. Oceanogr. 30: 1037-1045.

Chamberlain, H. D., 1975: A comparative study of the zooplankton communities of Skaneateles, Owasco, Hemlock and Conesus Lake. - Ph.D. dissertation, Cornell University, Ithaca, N.Y., USA

Crumpton, W. G., 1987: A simple and reliable method for making permanent mounts of phytoplankton for light and fluorescence microscopy. - Limnol. Oceanogr. 32: 1154-1159.

Forest, H. S., WAdE, J. Q. \& MAXwell, T. F., 1978: The Limnology of Conesus Lake. - In: Bloomfield, J. A. (ed.): Lakes of New York State. Vol. 1. Ecology of the Finger Lakes: 122-223. - Academic Press, New York, USA.

Gilbert, J. J., 1988: Suppression of rotifer populations by Daphnia: A review of the evidence, the mechanisms, and the effects on zooplankton community structure. - Limnol. Oceanogr. 33: 1286-1303.

Henry, R. L., 1985: The impact of zooplankton size structure on phosphorus cycling in field enclosures. - Hydrobiologia 120: 3-9.

MakareWicz, J. C., 1986. Water Quality of Conesus Lake. Prepared for the Villages of Avon and Geneseo, NY. Available from Drake Memorial Library, SUNY Brockport, Brockport, NY 14420.

McQueen, D. J., Johannes, M. R. S., Post, J. R., Stewart, T. J. \& LEAN, D. R. S., 1989: Bottom-up and top-down impacts on freshwater pelagic community structure. - Ecol. Monogr. 59: 289-309.

Mills, E. L., 1975: Phytoplankton composition and comparative limnology of Four Finger Lakes, with emphasis on lake typology. - Ph.D. dissertation, Cornell University, Ithaca, N.Y., USA.

Northcote, T. G., Arcifa, M. S. \& Munro, K. A., 1990: An experimental study of the effects of fish zooplanktivory on the phytoplankton of a Brazilian reservoir. - Hydrobiologia 194: 31-45.

Oglesby, R. T. \& Schaffner, W. R., 1978: Phosphorus loadings to lakes and some of their responses. Part 2. Regression models of summer phytoplankton standing crops, winter total phosphorus and transparency of New York lakes with known phosphorus loadings. - Limnol. Oceanogr. 23: 135-145.

Peters, R. H. \& Rigler, F. H., 1975. Phosphorus release by natural populations of limnetic zooplankton. - Verh. Internat. Verein. Limnol. 19: 273-279.

PucketT, N. L., 1989: Trophic level changes and alewife predation in Conesus Lake. - M.Sc. dissertation, State University of New York at Brockport, Brockport, NY, USA.

STEWART, K. M. \& Markello, S. J., 1974: Seasonal variations in concentrations of nitrate and total phosphorus, and calculated nutrient loading for six lakes in western New York. - Hydrobiologia 44: 61-89.

WeLLS, L., 1970: Effects of alewife predation on zooplankton populations in Lake Michigan. - Limnol. Oceanogr. 15: 556-565.

Wetzel, R. G. \& Likens, G. E., 1979: Limnological Analyses. Springer-Verlag, New York, USA. 391 pp.

Author's address:

J. C. MaKarewicz, 125 Lennon Hall, Department of Biological Sciences, State University of New York at Brockport, Brockport, NY, 14420 USA. 